\title{
Productivity of breeding pigs during marl feeding in areas with high density of soil pollution with radiocesium
}

\author{
Anna G. Menyakina*, Leonid N. Gamko, Vladimir A. Streltsov, and Tatiana L. Talyzina \\ Bryansk State Agrarian University, Bryansk, 243365, Russia
}

\begin{abstract}
The paper considers the experimentally confirmed data on marl efficiency in the zones with increased level of radionuclides in the soil $\left(5-10\right.$ and $\left.15-40 \mathrm{Ki} / \mathrm{km}^{2}\right)$ in the last third of female pig pregnancy in the amount of $2.0 \%$ of the diet dry matter. Feeding with local mineral supplement increases the reproductive functions of breeding pigs, in particular, the number of stillborn piglets decreased by $1.64-7.70 \%$ and their safety to weaning increased by $4.8-11.9 \%$. The increase of redox and metabolic processes in the animal body of the experimental groups positively affected the milking capacity of the breeding stock increasing it by $6.8-21.9 \%$ and the growth of piglets, which was confirmed by their larger body weight by 3.3 and $4.6 \%$. The sorption properties of marl allowed reducing the concentration of toxic lead in the body of breeding pigs (by 40.17 and $42.01 \%$ ) and cadmium (by 20.57 and $24.42 \%$ ), decreasing the transition of cesium-137 isotope to beestings milk by 1.34 and 1.28 times. In areas with high soil pollution with radiocesium in Bryansk region, the use of natural marl sorbent in breeding pigs' diets activates their immunity, hematopoietic functions, accelerates assimilation of protein and mineral exchange.
\end{abstract}

\section{Introduction}

In the Russian Federation, the agricultural production is carried out in different natural and climatic zones, which have their own mineral composition of soil, organic component, which largely determines the nutritional value of fodders, the full feeding value of farm animals and poultry.

The territory of Bryansk region was previously subject to radioactive contamination as a result of the Chernobyl nuclear power plant disaster, which resulted in the withdrawal of a large proportion of agricultural lands in five municipal areas. An important factor in reducing the contamination of pig products, especially in farms with high levels of radioactive contamination, has been the use of various agents that partially block their absorption from the digestive tract into the blood. The sorption properties of natural mineral additives are used to remove the excessive amount of anti-nutrient substances, underoxidized biological exchange products, which got into the animal organism from natural technogenic emissions.

The regional analysis of the territorial zones of the country shows that at a relatively small depth there is a huge reserve of natural mineral compounds with high biological properties, relative to both sorption and desorption of many biogenic food elements. Bryansk region also has deposits of natural sorbents with different mineral composition.

However, in the use of already known additives having sorption properties of both import and domestic production, there is one limiting factor - their cost. In this regard, the use of cheap local regional mineral raw materials - marl allows increasing the economic efficiency of the industry, which is always relevant for large producers and especially for farmers.

The possibility of using marl as a sorbent in decontamination of areas polluted with heavy metal emissions from metallurgical plants, thermal power plants, increased doses of radionuclides of artificial and natural origin is not excluded. However, the issues of decontamination of the animal body with the use of mineral feed additives of local regional raw materials have not been fully studied, but have recently been relevant.

The results of our study are consistent with the data of a number of foreign and domestic authors [1-11], who used zeolite-containing rocks and mineral-vitamin feeding in their experiments, which note the positive influence of natural sorbing minerals in the composition of pigs' diets on the change of their body weight, as well as on the reproduction indicators of breeding pigs.

\section{Materials and methods}

Marl is a sedimentary rock of mixed clay-carbonate composition consisting of calcite or dolomite and clay minerals. It is a rock occupying an intermediate position between limestone and dolomites on the one hand, and clays on the other. The laboratory studies using X-ray fluorescence analysis (XRF method) showed that marl includes a wide range of macro- and microelements required by animals. The maximum specific gravity in the overall structure of the chemical composition of marl

Corresponding author: menyakina77@yandex.ru 
is taken by calcium (at least $25 \%$ ) and classified as calcite.

Breeding pigs were selected by the method of pairs of analogues into control and experimental groups of 6 heads each taking into account breed, age, body weight and state of health. All 4 groups of animals (two in each zone) were kept under the same conditions. Breeding pigs were fed with marl during the last 30 days of their pregnancy in a dose of $2.0 \%$ of the dry matter.

The reproductive qualities of large white breeding pigs over two years of age kept in territories with different density of cesium pollution - 137 (from $5-10 \mathrm{Ki} / \mathrm{km}^{2}$ to 15-40 Ki/ $\mathrm{km}^{2}$ ) were studied according to the following features: big fetus (body weight of one piglet at birth, $\mathrm{kg}$ ), prolificacy (number of piglets at birth, heads), milking capacity (fetus weight on the $21^{\text {st }}$ day, $\mathrm{kg}$ ), weaning weight on the $60^{\text {th }}$ day $(\mathrm{kg})$, average weight of one weaning piglet $(\mathrm{kg})$, livability of young stock $(\%)$. The colostrum of breeding pigs was analyzed for the content of biogenic, toxic metals and radioactive cesium.

\section{Results}

The main diet of breeding pigs in the first $\left(5-10 \mathrm{Ki} / \mathrm{km}^{2}\right)$ and second $\left(15-40 \mathrm{Ki} / \mathrm{km}^{2}\right)$ experiments was identical and consisted of feed mixture: wheat stock feed - 7.2, oat stock feed -28.8 , barley stock feed -44.1 and clover herbage $-19.9 \%$ in terms of energy nutrition. The grain part of the diet, as well as the clover herbage were collected locally. The concentration of the main rated values in $1 \mathrm{~kg}$ of dry matter was as follows: $12.62 \mathrm{MJ}-$ exchange energy, $140.9 \mathrm{~g}$ - crude protein, $102.8 \mathrm{~g}-$ digestible protein, $127.3 \mathrm{~g}$ - crude fiber, $5.0 \mathrm{~g}$ - lysine, $3.73 \mathrm{~g}-$ methionine + cystine. The inclusion of marl in feed mixture reduced iodine deficiency, which is a critical microelement for breeding pigs. Calcium concentration in $1 \mathrm{~kg}$ of diet of breeding pigs of the experimental group increased to $12.9 \%$, phosphorus - to $4.02 \%$.

When tested at the age of 84-85 days, the pregnancy of the compared groups in both the first and second experiments did not have significant differences in body weight.

Table 1. Change of the body weight of breeding pigs under the influence of marl in the I zone

\begin{tabular}{|l|c|c|}
\hline \multirow{2}{*}{\multicolumn{1}{|c|}{ Indicator }} & \multicolumn{2}{c|}{$\begin{array}{c}\text { Soil contamination density with } \\
\text { radionuclides }\left(\mathrm{Cs}_{137}\right) 5-10 \mathrm{Ki} / \mathrm{km}^{2}\end{array}$} \\
\cline { 2 - 3 } & \multicolumn{2}{|c|}{ Animal group } \\
\cline { 2 - 3 } & $\mathrm{I}$ - control & II - experimental \\
\hline $\begin{array}{l}\text { Body weight at the } \\
\text { beginning of the } \\
\text { experiment, } \mathrm{kg}\end{array}$ & $253.12 \pm 2.47$ & $249.73 \pm 3.66$ \\
\hline $\begin{array}{l}\text { Body weight at the day } \\
\text { of farrowing, } \mathrm{kg}\end{array}$ & $26.792 \pm 2.54$ & $265.84 \pm 4.05$ \\
\hline $\begin{array}{l}\text { Absolute growth over } \\
\text { the experiment, kg }\end{array}$ & $\begin{array}{l}14.80 \\
\pm 0.28\end{array}$ & $16.11 \pm 0.43^{*}$ \\
\hline $\begin{array}{l}\text { Average daily growth } \\
\text { over the experiment, g }\end{array}$ & $\begin{array}{l}0.493 \\
\pm 0.01\end{array}$ & $0.537 \pm 0.014 * *$ \\
\hline
\end{tabular}

Note henceforward: *P $<0.05 ; * * \mathrm{P}<0.01 ; * * * \mathrm{P}<0.001$
Marl feeding of breeding pigs in the last 30 days of pregnancy had a positive impact on the increase in the completeness of their diet, which led to the increase in their body weight during this tensest period, obviously due to better absorption and redundancy of nutrients and minerals in their bodies, and as a result - an increase in the growth of their body weight.

At the end of the accounting period - on the day after farrowing it was stated that the uterus weight of experimental groups was slightly behind the control group - by $0.77 \%$ in the first experiment and by $0.55 \%$ in the second, which may be explained by heavier fetus. During the period of marl feeding, the average daily uterus gain of experimental groups was more than their control analogues - on average by 44 and $43 \mathrm{~g}$ respectively in the zones of experiments.

The calculation of the absolute increase over the period of the experiment reliably confirms more intensive growth of the body weight of breeding pigs of the experimental groups: in the first zone $\left(5-10 \mathrm{Ki} / \mathrm{km}^{2}\right)$ it was more by $8.85 \%$, and in the second zone (15-40 $\mathrm{Ki} / \mathrm{km}^{2}$ ) it exceeded the target by $8.94 \%$ (Table 1 and 2).

Table 2. Change of the body weight of breeding pigs under the influence of marl in the II zone

\begin{tabular}{|l|c|c|}
\hline \multirow{2}{*}{\multicolumn{1}{|c|}{ Indicator }} & \multicolumn{2}{|c|}{$\begin{array}{c}\text { Soil contamination density with } \\
\text { radionuclides }\left(\mathrm{Cs}_{137}\right) 15-40 \mathrm{Ki} / \mathrm{km}^{2}\end{array}$} \\
\cline { 2 - 3 } & \multicolumn{2}{|c|}{ Animal group } \\
\cline { 2 - 3 } & $\mathrm{I}$ - control & II - experimental \\
\hline $\begin{array}{l}\text { Body weight at the } \\
\text { beginning of the } \\
\text { experiment, } \mathrm{kg}\end{array}$ & $251.70 \pm 3.55$ & $248.97 \pm 2.97$ \\
\hline $\begin{array}{l}\text { Body weight at the } \\
\text { day of farrowing, } \mathrm{kg}\end{array}$ & $265.92 \pm 3.54$ & $264.45 \pm 3.23$ \\
\hline $\begin{array}{l}\text { Absolute growth } \\
\text { over the experiment, } \\
\text { kg }\end{array}$ & $14.21 \pm 0.14$ & $15.48 \pm 0.34^{* *}$ \\
\hline $\begin{array}{l}\text { Average daily } \\
\text { growth over the } \\
\text { experiment, g }\end{array}$ & $0.473 \pm 0.01$ & $0.516 \pm 0.01^{*}$ \\
\hline
\end{tabular}

Table 3. Reproductive qualities of breeding pigs in case of marl feeding in I zone

\begin{tabular}{|l|c|c|}
\hline \multirow{2}{*}{\multicolumn{1}{|c|}{ Indicator }} & \multicolumn{2}{c|}{$\begin{array}{c}\text { Soil contamination density with } \\
\text { radionuclides (Cs } 137) 5-10 \mathrm{Ki} / \mathrm{km}^{2}\end{array}$} \\
\cline { 2 - 3 } & \multicolumn{2}{|c|}{ Animal group } \\
\cline { 2 - 3 } & $\mathrm{I}$ - control & II - experimental \\
\hline $\begin{array}{l}\text { Prolificacy, total } \\
\text { including alive and } \\
\text { stillborn }\end{array}$ & $\begin{array}{c}65 \\
5\end{array}$ & $\begin{array}{c}66 \\
4\end{array}$ \\
\hline Big fetus, kg & $0.96 \pm 0.015$ & $1.03 \pm 0.014 * *$ \\
\hline $\begin{array}{l}\text { Average milking } \\
\text { capacity, kg }\end{array}$ & $27.67 \pm 0.03$ & $33.73 \pm 0.04 * *$ \\
\hline $\begin{array}{l}\text { Body weight of 1 head } \\
\text { on the 21 } 1^{\text {st }} \text { day, kg }\end{array}$ & $3.99 \pm 0.038$ & $4.41 \pm 0.052^{* * *}$ \\
\hline $\begin{array}{l}\text { Body weight of 1 head } \\
\text { at weaning, kg }\end{array}$ & $17.80 \pm 0.091$ & $18.39 \pm 0.065 * * *$ \\
\hline $\begin{array}{l}\text { Average weight of one } \\
\text { weaning piglet, g }\end{array}$ & $280.32 \pm 1.37$ & $284.41 \pm 4.83 *$ \\
\hline $\begin{array}{l}\text { Livability of young } \\
\text { stock, \% }\end{array}$ & 83.3 & 95.2 \\
\hline
\end{tabular}


Marl included into the diet of breeding pigs proved to be effective in increasing the level of genetic potential of their reproduction function (Tables 3 and 4).

Marl feeding of breeding pigs in the last third of pregnancy, in addition to endocrine changes affecting the growth and development of placenta, had a significant effect on the transmission of nutrients through it and gives them an advantage in their transformation, activation of assimilation processes, reduction of toxic effect, which in general had a positive impact not only on their own growth, but also on the development of embryos, post-embrionic growth and the preservation of the obtained fetus, as confirmed by experimental data.

The amount of fetus produced indicates that marl included in the feed mixture of breeding pigs in the last third of pregnancy, regardless of the area of their housing, did not affect the prolificacy. The percentage of stillborn piglets in breeding pigs of the control group in the conditions of the first zone $\left(5-10 \mathrm{Ki} / \mathrm{km}^{2}\right)$ was $7.70 \%$, and in the experimental one decreased by $1.64 \%$.

When the breeding pigs were kept in the second zone, where the density of soil contamination with radiocesium was $15-40 \mathrm{Ki} / \mathrm{km}^{2}$, there were $2.80 \%$ less stillborn piglets in the experimental group. At the same time, the breeding pigs of experimental groups in both zones differed from control ones by significantly higher fetus (by 7.3 and $5.9 \%$ at $\mathrm{P}<0.01$ ).

Table 4. Reproductive qualities of breeding pigs in case of marl feeding in the II zone

\begin{tabular}{|c|c|c|}
\hline \multirow{3}{*}{ Indicator } & \multirow{2}{*}{\multicolumn{2}{|c|}{$\begin{array}{c}\text { Soil contamination density with } \\
\text { radionuclides }\left(\mathrm{Cs}_{137}\right) 15-40 \mathrm{Ki} / \mathrm{km}^{2} \\
\text { Animal group } \\
\end{array}$}} \\
\hline & & \\
\hline & I - control & II - experimental \\
\hline $\begin{array}{l}\text { Prolificacy, total } \\
\text { including alive and } \\
\text { stillborn }\end{array}$ & $\begin{array}{c}67 \\
62 \\
5\end{array}$ & $\begin{array}{c}64 \\
61 \\
3\end{array}$ \\
\hline Big fetus, $\mathrm{kg}$ & $1.01 \pm 0.014$ & $1.07 \pm 0.015^{* *}$ \\
\hline $\begin{array}{l}\text { Average milking } \\
\text { capacity, } \mathrm{kg}\end{array}$ & $29.80 \pm 0.05$ & $31.82 \pm 0.05^{* *}$ \\
\hline $\begin{array}{l}\text { Body weight of } 1 \\
\text { head on the } 21^{\text {st }} \text { day, } \\
\mathrm{kg}\end{array}$ & $4.05 \pm 0.06$ & $4.26 \pm 0.06^{*}$ \\
\hline $\begin{array}{l}\text { Body weight of } 1 \\
\text { head at weaning, } \mathrm{kg}\end{array}$ & $17.45 \pm 0.09$ & $18.26 \pm 0.15 * * *$ \\
\hline $\begin{array}{l}\text { Average weight of } \\
\text { one weaning piglet, } g\end{array}$ & $273.84 \pm 1.37$ & $286.33 \pm 2.38 * * *$ \\
\hline $\begin{array}{l}\text { Livability of young } \\
\text { stock, \% }\end{array}$ & 91.9 & 96.7 \\
\hline
\end{tabular}

The milking capacity of breeding pigs was higher in the groups receiving marl in the diet with different degree of contamination with radionuclides and amounted to 33.76 and $31.82 \mathrm{~kg}$ in experimental groups, which exceeds the level of milking capacity of the control animals in the first and second experiments by 21.9 and $6.8 \%$ respectively. Besides, they have improved the biological completeness of colostrum they produce.

The data on colostrum samples of experimental breeding pigs (Table 5 and 6) taken for biochemical analysis for the content of biogenic and toxic metals, ecological control on the content of radiocesium, confirm not only the reduction of toxicological load due to the adsorption properties of marl on their body, but also prove its direct effect on their offspring, which is confirmed by its better preservation and higher growth rate.

Thus, the daily increases of piglets were more when their mothers were fed with marl - by 1.5 and $4.6 \%$, which allowed exceeding the body weight of control analogues at the moment of weaning (at the age of 60 days) by 3.3 and $4.6 \%$ respectively in the growing zones. The livability of young stock in experimental groups was also increased: in the first zone $\left(5-10 \mathrm{Ki} / \mathrm{km}^{2}\right)-$ by $11.9 \%$, and in the second zone $\left(5-40 \mathrm{Ki} / \mathrm{km}^{2}\right)-$ by $4.8 \%$.

The negative impact of the environmental factor is undoubtedly reflected in the decrease in the quality and biosafety of milk in milking breeding pigs. Radioactive cesium is known to be a chemical analogue of potassium, it is well absorbed when ingested with feed, relatively uniformly irradiates all organs and tissues, it is deposited mainly in the muscle tissue, and in milking breeding pigs it is actively released with colostrum and milk. Considering that the rate of ${ }^{137} \mathrm{Cs}$ transition from diet to milk is much higher $\left(5-10\right.$ times) than ${ }^{90} \mathrm{Sr}$ we have established the level of excretion of cesium isotopes from the colostrum of breeding pigs, which were received marl with feed mixture.

Table 5. Concentration of biogenic, heavy metals and cesium137 in breeding pigs' colostrum in I zone

\begin{tabular}{|c|c|c|}
\hline \multirow{3}{*}{ Indicator } & \multicolumn{2}{|c|}{$\begin{array}{l}\text { Soil contamination density with } \\
\text { radionuclides }\left(\mathrm{Cs}_{137}\right) 5-10 \mathrm{Ki} / \mathrm{km}^{2}\end{array}$} \\
\hline & \multicolumn{2}{|c|}{ Animal group } \\
\hline & I - control & II - experimental \\
\hline Iron, $\mathrm{mg} / \mathrm{l}$ & $5.6832 \pm 0.2318$ & $5.1752 \pm 0.0451$ \\
\hline Zinc, $\mathrm{mg} / \mathrm{l}$ & $5.8480 \pm 0.0617$ & $4.7845 \pm 0.0257 * * *$ \\
\hline Copper, mg/l & $0.7041 \pm 0.0032$ & $0.6822 \pm 0.0089$ \\
\hline Cadmium, mg/l & $0.0209 \pm 0.0014$ & $0.0166 \pm 0.0003^{*}$ \\
\hline Lead, mg/l & $0.0824 \pm 0.0017$ & $0.0493 \pm 0.0020 * * *$ \\
\hline $\begin{array}{l}\text { Cesium-137, } \\
\text { mg/l }\end{array}$ & $41.0325 \pm 2.3867$ & $30.7125 \pm 2.4678 *$ \\
\hline
\end{tabular}

Table 6. Concentration of biogenic, heavy metals and cesium137 in breeding pigs' colostrum in II zone

\begin{tabular}{|l|c|c|}
\hline \multirow{2}{*}{\multicolumn{1}{|c|}{ Indicator }} & \multicolumn{2}{|c|}{$\begin{array}{c}\text { Soil contamination density with } \\
\text { radionuclides }\left(\mathrm{Cs}_{137}\right) 15-40 \mathrm{Ki} / \mathrm{km}^{2}\end{array}$} \\
\cline { 2 - 3 } & \multicolumn{2}{|c|}{ Animal group } \\
\cline { 2 - 3 } & $\mathrm{I}-$ control & $\mathrm{II}-$ experimental \\
\hline Iron, $\mathrm{mg} / \mathrm{l}$ & $5.7150 \pm 0.2135$ & $5.1331 \pm 0.0234$ \\
\hline Zinc, $\mathrm{mg} / \mathrm{l}$ & $5.8581 \pm 0.0365$ & $4.5634 \pm 0.1951^{* * *}$ \\
\hline Copper, $\mathrm{mg} / \mathrm{l}$ & $0.7132 \pm 0.0072$ & $0.6938 \pm 0.0102$ \\
\hline Cadmium, mg/l & $0.0217 \pm 0.0008$ & $0.0164 \pm 0.0005^{* *}$ \\
\hline Lead, $\mathrm{mg} / \mathrm{l}$ & $0.0876 \pm 0.0006$ & $0.0508 \pm 0.0019^{* * *}$ \\
\hline $\begin{array}{l}\text { Cesium-137, } \\
\mathrm{mg} / \mathrm{l}\end{array}$ & $59.1775 \pm 3.1788$ & $46.0725 \pm 0.8244^{* *}$ \\
\hline
\end{tabular}

The results of colostrum analysis suggest that the administration of marl to the breeding pigs at a dose of $2 \%$ of the dry matter significantly $(\mathrm{P}<0.05-0 / 001)$ reduces its toxic metal content such as zinc (by 18.19 and $22.1 \%$ ), lead (by 40.17 and $42.01 \%$ ), cadmium (by 20.57 and $24.42 \%$ ), as well as radioactive cesium-137 
(by 25.15 and $22.14 \%$ ) and its level corresponded to Hygienic Requirements for Quality and Safety of Food Raw Materials and Food Products SanPiN 2.3.2.1078-01. Obviously, when the mineral natural sorbent enters the gastrointestinal tract, it strongly binds cesium, converting it into an insoluble form, preventing secondary reabsorption, thereby reducing the level of milk contamination. Iron and copper levels remained stable.

The blood of breeding pigs of the compared groups is characterized by significant differences with high degree of reliability in favor of the breeding pigs of experimental groups in terms of erythrocyte content (by $13.9 \%, \mathrm{P}<0.01$ ), hemoglobin level (by $12.9 \%, \mathrm{P}<0.05$ ). Consequently, the consumption of natural marl sorbent by breeding pigs activates the course of redox processes in their bodies.

The introduction of marl into the diet of breeding pigs contributed to the strengthening of the protective functions of the body. The leukocyte content was higher by $17.1 \%(\mathrm{P}<0.05)$ than in the blood of control animals. The increase in blood-forming function of bone marrow was apparently a response to toxic metabolic and tissue degradation products, including an increase in leukocytes, which is typical for the area with high degree of radiocesium contamination.

Blood serum of breeding pigs of experimental groups was characterized by high content of total protein - by 6.0 and $7.5 \%(\mathrm{P}<0.001)$ mainly due to increased fraction of globulins - by 7.19 and $9.2 \%$, which, in our opinion, indicates the activation of protective reactions of their organism. The content of calcium and phosphorus in the blood confirms that mineral metabolism in the body of breeding pigs in the zones with different density of contamination with radionuclides was more intense, which positively affected the productive qualities of breeding pigs when fed as part of the marl diet. Due to the change in the concentration of calcium and phosphorus in the serum of the uterus, their ratio has become more optimal.

The use of cheap local mineral sorbents reduces the cost of pork production and is technologically feasible, as there are no costs for transporting such sorbents from other regions, and their price is minimal and advantageously differs from natural mineral additives from other regions of the Russian Federation, especially imported products.

When marl is included in the composition of feed mixture in the first zone, the profit from the sale of piglets at 2 months of age was more by $62.5 \%$ and in the second zone - by $18 \%$ than the similar indicator in the control group, which proves the economic expediency of using sorbents.

\section{Conclusion}

Due to the fact that marl contains deficient mineral substances, when entering the animal body, it is able to improve the synthesis of protein and other compounds, facilitate the course of normal metabolic reactions without changing their direction and biological essence.
Its sorption properties make it possible to eliminate the effect of heavy metals and radionuclides forming a strong insoluble complex, removes from the body mainly with potassium and thus exhibits its anticarcinogenic and antiteratogenic effect, including protection against radiation and regulating specific and non-specific immunity.

Thus, it is recommended to include marl at a dose of $2.0 \%$ of the dry matter into the diet of breeding pigs in the last third of their pregnancy, which will reliably increase the intensity of their growth, achieve optimal body weight by farrowing and further lactation, significantly reduce the level of xenobiotics and radiocesium in colostrum, improve their physiological status and allow better realization of genetic potential of reproductive qualities.

\section{References}

1. A. Wawrzyniak et al., Effect of Feeding Transcarpathian Zeolite on astrointestinal Morphology and Function in Broiler Chickens, Revista Brasil. de Ciência Avícola 19, 737-746 (2017)

2. H. Valpotić et al., Zeolite clinoptilolite nanoporous feed additive for animals of veterinary importance: potentials and limitations, Period. Biology. 119, 159-172 (2017)

3. K. Männer, H. Hundhausen, Effektie unterschiedelicher Chelate auf die Bioverfügbarkeit, Kraftfutter 93, 21-25 (2010)

4. T.L. Talyzina, L.N. Gamko, V.V. Talyzin, V.E. Podolnikov, Peculiarities Of Metabolism In Young Pigs When Using Zeolite-Containing Additives, Res. J. of Pharmac., Biolog. and Chem. Sci. 10(3), 345-349 (2019)

5. A.V. Kornienko, V.E. Ulitko, L.A. Pykhtina, E.V. Savina, Chemical composition of colostrum and breeding pig milk when used in diets of probiotic and sorbing pre-probiotic additives, Zootechn. 3, 25-27 (2016)

6. A.G. Menyakina, L.N. Gamko, Application of natural sorbent additives in the diets of young pigs and their influence on the content of heavy metals in organs and tissues, Zootechn. 3, 14-16 (2018)

7. A.G. Naryzhny, A.T. Mysik, N.I. Kreindlina, A.Ch. Dzhamaldinov, A.V. Repin, Use of vitaminmineral preparation Karzesel to enhance reproductive qualities of breeding pigs, Zootechn. 2, 29-30 (2015)

8. A.T. Mysik, R.V. Necrasov, M.G. Chabaev, E.A. Makhaev, M.B. Badyrkhanov, I.M. Magomedaliev, Peculiarities of the system of normalized feeding of pigs in LLC TSAR MEAT of Bryansk region, Zootechn. 9, 14-17

9. V.E. Ulitko, Yu.V. Semyonova, E.V. Savina, L.A. Pychtina, O.A. Desyatov, Productivity of pigs during the use of feed additive with sorbing and 
probiotic properties in their diets, Zootechn. 7, 2527 (2018)

10. V.E. Ulitko, A.V. Kornienko, Productivity of breeding pigs in conditions of industrial technology of pork production when using biologically active additives, Zootechn. 3, 12-18 (2017)
11. V.F. Engovatov, A.M. Morozov, A.S. Nabiullin, K.L. Kosarev, A.V. Kudryashov, Comparative efficiency assessment of sorbent use in mixed feed for piglets, Zootechn. 11, 10-12 (2015) 